\title{
Transplanting Date Influences Winter Injury and Growth of Two Azalea Cultivars
}

\author{
G. J. Keever', \\ G.S. Cobb $^{2}$, and \\ W.J. Foster ${ }^{2}$
}

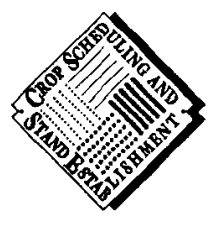

Additional index words. crop scheduling, Rhododendron indicum 'Formosa', R. obtusum 'Hino Crimson'

Summary. Plant response to time of transplanting from 0.53-qt (OSliter) to 1-gal (3.8-liter) containers was influenced by cultivar and severity of winter. Transplanting of 'Formosa' from Sept. through Dec. 1983 resulted in injury and death of many plants due to a low temperature of $8 \mathrm{~F}(-13.3 \mathrm{C})$ in Dec. 1983. Injury or death of 'Hino Crimson' was higher when plants were transplanted in December. Survival and growth indices of both cultivars were higher when transplanted in January through March. During 1986-87, when minimum temperature was $26 \mathrm{~F}(-3.3 \mathrm{C})$, transplanting between September and April had minimal effect on growth of 'Formosa', but plant quality was better when plants were transplanted between December and April. Transplanting date had little effect on size of 'Hino Crimson', except smaller plants were produced when transplanted in April; quality was highest of plants transplanted from November through March.

$\mathrm{T}$ here are no nursery standards in the southeastern United States regarding how long rooted cuttings are held following propagation before being transplanted into larger containers for continued growth. Cuttings from recently matured growth of many species in nurseries along the Gulf Coast are taken from May through July. Peak trans-

${ }^{7}$ Associate Professor, Department of Horticulture and the Alabama Agricultural Experiment Station, Auburn University, AL 36849-5408.

${ }^{2}$ Former Superintendent, Ornamental Horticulture Substation, Alabama Agricultural Experiment Station, Mobile, AL 36608-0276. 
planting usually occurs from April through June; earlier transplanting may be limited by the need for winter protection or shipping demands.

Most information on how transplanting time affects subsequent plant growth is based on research with tree species, and results often are inconsistent. Harris et al. (1971) reported that, for most species, the earlier tree seedlings were transplanted into larger containers the more the plants grew in caliper and height, and the more extensive was the root development; however, time of transplanting did not affect shoot growth of Chinese pistache. In other research (Whitcomb et al., 1977; Appleton and Whitcomb, 1983), earlier transplanting dates enhanced shoot growth ofseveral species, but not of Chinese pistache or five species of pine. It was suggested that early transplanting is more beneficial to fast-growing species, but negligible in effect on slower-growing coniferous trees (Whitcomb, 1984). Our study was conducted to determine how transplanting time affects growth of two azalea cultivars in southern Alabama.

Uniform 3-inch $(8.3-\mathrm{cm})$ cuttings of 'Formosa' and 'Hino Crimson' azaleas were treated with a 5-sec quick dip of 1600 and 1200 ppm, respectively, $1 \mathrm{H}$-indole-3-butanoic acid (IBA) on 6 May 1983. Cuttings were placed in a greenhouse under intermittent mist in 0.53 -qt (0.5-liter) peat pots using a $100 \%$ milled pine bark medium amended per cubic yard $\left(\mathrm{m}^{3}\right)$ with $6 \mathrm{lb}$ (3.6 kg) dolomitic limestone, $2 \mathrm{lb}(1.2$ $\mathrm{kg}$ ) superphosphate, $2 \mathrm{lb}(1.2 \mathrm{~kg})$ gypsum, and $1.5 \mathrm{lb}(0.9 \mathrm{~kg})$ Micromax micronutrient fertilizer (Grace-Sierra Co., Milpitas, Calif.). Booted cuttings were held in a double polyethylene greenhouse with a 55F (13C) minimum night temperature and were fertilized weekly with $150 \mathrm{ppm} \mathrm{N}$ from 20N-4.3P-16.6K (20-10-20). Beginning 15 Sept. 1983 and continuing monthly through May 1984, 25 liners of each cultivar were transplanted into l-gal (3.8-liter) containers. The growth medium was $100 \%$ milled pine bark amended as above, except for the incorporation of $10 \mathrm{lb} / \mathrm{yd}^{3}\left(5.9 \mathrm{~kg} \cdot \mathrm{m}^{-3}\right)$ of $17 \mathrm{~N}-3 \mathrm{P}-10 \mathrm{~K}$ (Osmocote 17-712, Grace-Sierra). Immediately following transplanting, plants were placed under $47 \%$ shade in an outdoor production area. Plants were placed pot-to-pot for winter protection from December through February, with no other winter protection being provided. Plants were topdressed on 13 Aug. 1984 with 1 level teaspoon (4 g) of $19 \mathrm{~N}-2.6 \mathrm{P}-10 \mathrm{~K}$ (Osmocote 19-612, Grace-Sierra). Plants were in a completely randomized design within cultivars and there were 25 singleplant replicates.

Winter injury of plants previously transplanted was rated on 6 Jan. 1984, using a 1 to 5 scale, where $1=$ no injury; $2-4=$ slight, moderate, and severe foliar necrosis and necrotic shoot tips; and 5 = entire shoots dead. Percentages of plants with split bark and alive were determined on $11 \mathrm{Apr}$. and 17 Sept. 1984, respectively. Growth indices, a nondestructive measure of shoot growth equal to the mean of plant height, width at the widest point, and width $90^{\circ}$ to the widest point were calculated on 29 May and 17 Sept. 1984. After growth indices measurements were made on 29 May, plants of 'Hino Crimson' and 'Formosa' were pruned to 4 -inch $(10.2-\mathrm{cm})$ and 6inch $(15-\mathrm{cm})$ heights, respectively. This procedure is common among nursery workers and necessary to produce compact, well-branched plants.

The experiment was repeated during 1986 and 1987 with the following changes: 1) the 15 May transplanting date was omitted; 2) plants were pruned and topdressed on 1 July 1987; and 3) growth indices were taken on 30 June and 22 Dec., a quality rating and a foliar color rating ( $1,3,5$ = light, medium, dark green) were made on Dec., and shoot dry weight was determined 4 Jan. 1988.

Entire shoots of 'Formosa' transplanted in Dec. 1983 were dead by Jan. 1984, while injury was slight to severe on plants transplanted prior to December (Table 1). Bark-splitting was present on $>90 \%$ of all plants transplanted in September through December. By Sept. 1984, survival was low for plants transplanted in September and October, and only $76 \%$ with November transplants, while all plants transplanted in December were dead. Surviving plants transplanted from September through December were smaller, as indicated by growth indices, than plants transplanted later, except for plants transplanted in April or May. An earlier transplanting date, provided it was after December, resulted in larger plants in both May and Sept. 1984; smallest plants had been transplanted in May. Observations indicated foliage color and root density were good to excellent for plants transplanted on all dates except MayMay transplants were chlorotic and roots penetrated only one-halfto twothirds of the depth of the container.

By Jan. 1984, severe necrosis of the foliage and shoot tips was present on 'Hino Crimson' transplanted in Dec. 1983; injurywas much less severe to plants transplanted earlier (Table 2). Splitting of bark did not occur with any treatment. By September, only $8 \%$ of plants transplanted in December were alive; survival of plants transplanted at other times was $88 \%$ or higher. Growth indices, measured in

Table 1. Effects of transplanting date on winter injury, survipal, and growtb of 'Formosa' asalea, 1983-84.

\begin{tabular}{|c|c|c|c|c|c|}
\hline \multirow{2}{*}{$\begin{array}{l}\text { Transplanting } \\
\text { date }\end{array}$} & \multirow{2}{*}{$\begin{array}{l}\text { Winter } \\
\text { injury } \\
\text { rating }\end{array}$} & \multirow{2}{*}{$\begin{array}{c}\text { Bark- } \\
\text { splitting' (\%) }\end{array}$} & \multirow{2}{*}{$\begin{array}{c}\text { Plant } \\
\text { survival (\%) }\end{array}$} & \multicolumn{2}{|c|}{ Growth indices $(\mathrm{cm})$} \\
\hline & & & & 29 May 1984 & 17 Sept. 1984 \\
\hline Sept. 1983 & 3.1 & 100 & 4 & 22.0 & 40.7 \\
\hline Oct. 1983 & 3.3 & 100 & 24 & 23.4 & 45.2 \\
\hline Nov. 1983 & 2.2 & 92 & 76 & 23.6 & 40.9 \\
\hline Dec. 1983 & 4.8 & 100 & 0 & -- & $-\cdots$ \\
\hline Jan. 1984 & $\ldots w$ & -- & 100 & 31.6 & 51.7 \\
\hline Feb. 1984 & $\cdots$ & ... & 100 & 30.6 & 53.0 \\
\hline Mar. 1984 & $\ldots$ &.-- & 100 & 24.5 & 50.8 \\
\hline Apr. 1984 & --- & --- & 100 & 23.0 & 46.6 \\
\hline May 1984 & -- & --- & 100 & 21.7 & 29.1 \\
\hline Significance $^{v}$ & $\mathrm{C}$ & & & $\mathrm{Q}$ & $\mathrm{C}$ \\
\hline
\end{tabular}

"I = no injury; 2-4 = slight, moderate, and sepere foliar necrosis and necrotic tips; 5 - entire shoots deadrated 6 Jan. 1984

Percent of plants exhibiting bark-splitting-determined 11 Apr. 1984.

${ }^{*}$ Growth indices $=$ (height + width at the widest point + width $90^{\circ}$ to widest point $)+3$.

"Treatment not transplanted when data were collected.

-Effects of transplanting date are significant at $\mathrm{P}=0.01$ and are quadratic $(Q)$ or cubic $(C)$. 
May 1984, decreased with later transplant dates. By September, this trend was less obvious, with only the April and May transplants having lower growth indices. Treatment effects on foliage color were similar to those observed with 'Formosa'. Root density decreased with the later transplant dates, but roots of plants transplanted before April were dense and penetrated the growth medium thoroughly.

Results obtained in 1986-87 contrasted with those obtained in 1983-84. No plants of either cultivar died as a result of transplanting date. Several random plants of 'Hino Crimson' died during Summer 1987; Phytophthora was isolated from the roots. Growth indices of both 'Formosa' and 'Hino Crimson', measured in June 1987, were highest with the September transplanting date, lower with October through March dates, and lowest for plants transplanted in April (Tables 3 and 4). Following pruning for compaction on 1 July, only slight differences in growth indices of 'Formosa' were apparent in Dec. 1988, while shoot dry weight and quality ratings are higher with later transplanting dates, particularly December or later. By Dec. 1988, growth indices of 'Hino Crimson' transplanted in Sept. 1987 were lower than those of plants transplanted in October through March, but lowest with plants transplanted in Apr. 1987. Shoot dry weight was similar among transplanting dates, except for a significant decrease with the April transplanting, while quality ratings were lower with September and April transplanting dates than with other transplanting dates. The apparent reversal of response to transplanting date with 'Formosa' may have been due to the removal of a larger proportion of the canopy of plants transplanted earlier, resulting in slower regrowth compared to plants transplanted later. A similar explanation may apply to 'Hino Crimson' transplanted in September. The slower growth rate of this cultivar relative to 'Formosa' may explain why plants transplanted in April were still much smaller in December than plants transplanted earlier. Foliar color was good to excellent for both cultivars transplanted on all dates, ranging from 4.2 to 4.7 with 'Formosa' and from 3.9 to 4.5 with 'Hino Crimson'. Treatments did not differ significantly in foliar color ratings.

Table 2. Effects of transplanting date on winter injury, survipah, and growth of 'Hino Crimson' aralea, 1983-84.

\begin{tabular}{|c|c|c|c|c|}
\hline \multirow{2}{*}{$\begin{array}{l}\text { Transplanting } \\
\text { date }\end{array}$} & \multirow{2}{*}{$\begin{array}{l}\text { Winter } \\
\text { injury } \\
\text { ratings }\end{array}$} & \multirow{2}{*}{$\begin{array}{c}\text { Plant } \\
\text { survival (\%) }\end{array}$} & \multicolumn{2}{|c|}{ Growth indices $(\mathrm{cm})$} \\
\hline & & & 29 May 1984 & 17 Sept. 1984 \\
\hline Sept. 1983 & I.0 & 88 & 32.2 & 33.1 \\
\hline Oct. 1983 & 1.0 & 88 & 31.8 & 34.3 \\
\hline Nov. 1983 & 2.3 & 92 & 26.8 & 34.0 \\
\hline Dec. 1983 & 3.9 & 8 & 24.3 & 34.9 \\
\hline Jan. 1984 & $\ldots x$ & 100 & 24.8 & 34.9 \\
\hline Feb. 1984 & ..- & 100 & 26.5 & 36.0 \\
\hline Mar. 1984 &.-- & 100 & 21.8 & 34.6 \\
\hline Apr. 1984 & $\cdots$ & 100 & 18.9 & 30.2 \\
\hline May 1984 &.- & 100 & 19.1 & 24.7 \\
\hline Significance ${ }^{w}$ & C & & $\mathrm{L}$ & $Q$ \\
\hline
\end{tabular}

Table 3. Effects of transplanting date on growth and quality of Fommosa' asalea, 1986-87.

\begin{tabular}{|c|c|c|c|c|}
\hline \multirow{2}{*}{$\begin{array}{l}\text { Transplanting } \\
\text { date }\end{array}$} & \multicolumn{2}{|c|}{ Growth indices $(\mathrm{cm})$} & \multirow{2}{*}{$\begin{array}{c}\text { Shoot } \\
\text { dry wt } \\
\text { (g) }\end{array}$} & \multirow{2}{*}{$\begin{array}{l}\text { Quality } \\
\text { rating }\end{array}$} \\
\hline & 30 June 1987 & 22 Dec. 1987 & & \\
\hline Sept. 1986 & 64.8 & 52.3 & 48.2 & 3.0 \\
\hline Oct. 1986 & 54.3 & 48.9 & 32.2 & 3.0 \\
\hline Nov. 1986 & 57.7 & 52.9 & 45.2 & 3.5 \\
\hline Dec. 1986 & 56.7 & 53.4 & 53.7 & 4.1 \\
\hline Jan. 1987 & 52.8 & 53.9 & 58.4 & 4.3 \\
\hline Feb. 1987 & 55.3 & 56.0 & 60.4 & 4.3 \\
\hline Mar. 1987 & 51.3 & 55.5 & 56.8 & 4.6 \\
\hline Apr. 1987 & 42.0 & 54.6 & 55.4 & 4.6 \\
\hline Significance $^{x}$ & C & $\mathrm{C}$ & C & $\mathrm{C}$ \\
\hline
\end{tabular}

${ }^{2}$ Growth indices = (beight + width at the widest point + width $90^{\circ}$ to widest point $)+3$.

'1 - extensipe shoot dieback or dead; 2 = chlorotic, poorly branched; 3 - light green; 4 = medium green, good branching; 5 = dark green, densely branched.

${ }^{x}$ Effects of transplanting date are significant at $\mathrm{P}=0.01$ and are cubic $(C)$.

Table 4. Effects of transplanting date on growth and quality of 'Hino Crimson' asalea, 198687.

\begin{tabular}{lcccc}
\hline Transplanting & \multicolumn{2}{c}{$\begin{array}{c}\text { Growth indices } \\
\text { date }\end{array}$} & $\begin{array}{ccc}\text { Shoot } \\
\text { dry wt } \\
(\mathrm{g})\end{array}$ & $\begin{array}{c}\text { Quality } \\
\text { rating }\end{array}$ \\
\cline { 2 - 5 } Sept. 1986 & 37.4 & 29.3 & 28.4 & 2.4 \\
Oct. 1986 & 31.9 & 34.8 & 24.9 & 3.2 \\
Nov. 1986 & 33.8 & 33.9 & 26.6 & 3.5 \\
Dec. 1986 & 30.0 & 36.2 & 30.4 & 4.2 \\
Jan. 1987 & 27.3 & 34.6 & 24.6 & 3.6 \\
Feb. 1987 & 27.9 & 36.1 & 30.5 & 3.9 \\
Mar. 1987 & 27.4 & 35.4 & 30.0 & 4.0 \\
Apr. 1987 & 14.7 & 17.7 & 3.9 & 2.5 \\
Significance & $\mathrm{C}$ & $\mathrm{C}$ & $\mathrm{C}$ & $\mathrm{Q}$ \\
\hline
\end{tabular}

${ }^{2}$ Growth indices $=\left(\right.$ beight + width at the widest point + width $90^{\circ}$ to widest point $)+3$.

'I = extensipe shoot dieback or dead; 2 - chlorotic, poorly branched; $3=$ light green; $4=$ medium green, good branching; 5 = dark green, densely branched.

${ }^{*}$ Effects of transplanting date are significant at $\mathrm{P}=0.01$ and are quadratic $(Q)$ or cubic $(C)$.

Response to transplanting dates varied with cultivar and year of testing. To a large degree, these differences may be explained by a difference in hardiness of the two cultivars and the greater severity of the 1983-84 winter compared to $1986-87$. 'Formosa' is more sensitive to low temperature than 'Hino Crimson'. Minimum temperatures averaged $48 \mathrm{~F}$ (8.9C) during the week prior to Christmas 1983. On 24 Dec., the temperature dropped to $22 \mathrm{~F}$ 
(-5.6C), the first day temperatures were $<32 \mathrm{~F}(0 \mathrm{C})$. The following day, the low temperature was $8 \mathrm{~F}(-13 \mathrm{C})$. Between 24 Dec. 1983 and 2 Jan. 1984, subfreezing temperatures were recorded on different days. Low temperatures in January, February, and Marchwere 18F (-7.8C),24F (-4.4C), and $28 \mathrm{~F}(-2.2 \mathrm{C})$, respectively. In contrast, the temperature dropped as low as 32F (0C) only once in Dec. 1986. In Jan. 1987, temperatures were $<33 \mathrm{~F}$ (0.6C) on five dates and the minimum temperature was $29 \mathrm{~F}(-1.7 \mathrm{C})$, while in February subfreezing temperatures [26F $(-3.3 \mathrm{C})]$ occurred once. These were the only incidents of freezing temperatures during Winter 1986-87.

A plant's response to time of transplanting is likely to be influenced by winter weather conditions as well as by the hardiness and vigor of the species or cultivar. Where winters are potentially severe, early transplanting of coldsensitive cultivars, such as 'Formosa', may result in injury or death if winter protection is not provided. A grower must weigh the increased costs of protecting plants in larger containers against the value of not having two highly labor-intensive tasks-shipping and transplanting-to deal with during the busy spring season. If plants are protected, transplanting dates of September through April may have little effect on growth of vigorous species, particularly if plants are pruned for compactness during the growing season. For slower-growing species, such as 'Hino Crimson', larger plants may be produced when transplanted early and protected during the winter; however, severe pruning may negate the benefit of greater growth early in the growing season.

\section{Literature Cited}

Appleton, B. and C.E. Whitcomb. 1983. Effects ofcontainer size and transplant date on the growth of tree seedlings. J. Environ. Hort. 1:89-93.

Harris, RW., W.B. Davis, N.W. Stice, and D. Long. 1971. Influence of transplanting time in nursery production. J. Amer. Soc. Hon. Sci. 96(1):109-110.

Whitcomb, C.E. 1984. Plant production in containers. Lacebark, Stillwater, Okla.

Whitcomb, C.E., A. Storjohann, and J.D. Gibson. 1977. Effects of time of transplanting container grown tree seedlings on subsequent growth and development. Okla. Agr. Expt. Sta. Res. Rpt. P 777:37-39. 